УДК 311:33]:620.92](477)

\title{
INFORMATION AND REGULATORY PROVISION FOR THE ESTIMATION OF RENEWABLE ENERGY SOURCES IN UKRAINE
}

DOI 10.30838/ P.ES.2224.290818.45.208

Khazan P.

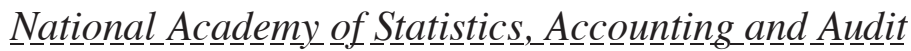
The global development of energy should be based exclusively on the concept of sustainable development. It means renewable energy with significant increase in energy efficiency, creating conditions for universal access to high-quality electrical and thermal energy. Renewable energy advantages are inexhaustibility of natural resources, low risk level for human health, minimization of negative impact on environment. The article analyses information and regulatory provision of the estimation of renewable energy sources towards justifying of theoretical and methodological bases for statistical estimation of renewables and developing scientific and practical recommendations for the implementation. National and international regulation are the basis for methodological, regulatory and informational provision for statistical estimation of renewable energy sources in Ukraine. The international legal framework is presented by directives and agreements: Directive 2006/32/EC, Directive 2009/28/EC, Treaty establishing the Energy Community, Regulation No. 1099/2008 of the European Parliament and of the Council, Energy Statistics Manual. Gradual harmonization of Ukrainian legislation according to the European and international regulatory system is being performed with respect to the Ukrainian Constitution. The main documents on the national level are: Law of Ukraine «On electricity», Law «On alternative energy sources», Law «On alternative fuels», The Law of Ukraine «On combined heat and power (cogeneration) and waste power utilization», Law of Ukraine «On energy saving» etc. The normative legal framework of renewable energy regulation in Ukraine is presented by extensive regulatory system. Further research on information and regulatory provision of renewable energy sources will address the «green» tariffs and new forms of financial support for development of renewable energy sources.

Keywords: renewable energy sources, development, statistical estimation, information and regulatory provision.

UDC 311:33]:620.92](477)

НОРМАТИВНО-ІНФОРМАЦЙНЕ ЗАБЕЗПЕЧЕННЯ ОЦІНЮАННЯ ВІДНОВЛЮВАНИХ ДЖЕРЕЛ ЕНЕРГЇ̈ В УКРАЇНІ

DOI 10.30838/ P.ES.2224.290818.45.208

Хазан П.В.

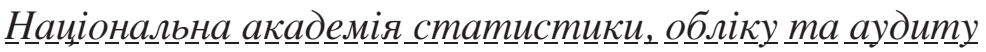

Глобальний розвиток енергетики має грунтуватися виключно на концепції сталого розвитку. Мається на увазі відновлювана енергетика при значному підвищенні

(C) Хазан П.В., 2018 
енергоефективності, створенні умов для загального доступу до якісної електричної та теплової енергії. Переваги відновлюваної енергетики - невичерпність природних ресурсів, низький рівень ризику для здоров'я людей, мінімізація негативного впливу на довкілля. У статті аналізується нормативно-інформаційне забезпечення оцінювання відновлюваних джерел енергії з метою обгрунтування теоретичних та методологічних основ статистичного оцінювання відновлюваних джерел енергії та розробки науково-практичних рекомендацій щодо їх впровадження. Національні та міжнародні нормативно-правові документи є основою методологічного, правового та інформаційного забезпечення статистичної оцінки відновлюваних джерел енергії в Україні. Міжнародна нормативно-правова база представлена директивами та угодами: Директива 2006/32/ЄС, Директива 2009/28/ЄС, Договір про заснування Енергетичного Співтовариства, Постанова № 1099/2008 Європейського Парламенту та Ради, Посібник зі статистики енергетики. Поступова гармонізація українського законодавства до європейської та міжнародної нормативно-правової системи відбувається відповідно до Конституції України. Основними документами на національному рівні є: Закон України «Про електроенергетику», Закон України «Про альтернативні джерела енергії», Закон України «Про альтернативні види палива», Закон України «Про комбіноване виробництво теплової та електричної енергії (когенерацію) та використання скидного енергопотенціалу», Закон України «Про енергозбереження» тощо. Нормативно-правове забезпечення регулювання відновлюваної енергетики в Україні представлено розгалуженою системою регулювання. Подальші дослідження нормативно-інформаційного забезпечення відновлюваних джерел енергії будуть спрямовані на «зелені» тарифи та нові форми фінансової підтримки розвитку відновлюваних джерел енергії.

Ключові слова: відновлювані джерела енергії, розвиток, статистичне оцінювання, нормативно-інформаційне забезпечення.

Introduction. On September 25, 2015, the United Nations adopted «Sustainable Development Goals» in New York, USA. One of the goals defined by the strategic document is focused of energy. Goal № 7 «Ensure access to affordable, reliable and modern energy» declares the need for universal provision of financially accessible, modern energy.

The global development of energy should be based exclusively on sustainable and renewable energy with significant increase in energy efficiency, creating conditions for universal access to high-quality electrical and thermal energy. The transition period to one hundred percent using of renewable energy sources (RES) may include the use of fossil fuels only in the absence of its negative impact on environment in the process of energy conversion. [1, 2]. As stated in a number of UN core documents, meaningful improvements will require higher level of funding and more responsive policy commitments, as well as the willingness of countries to apply new technologies 
on a much wider scale. Solar and wind power still account for a relatively small share of energy consumption, despite their rapid growth in recent years. The task is to increase the share of RES in heat and electricity generation and transport sectors [3].

The Paris Agreement under the United Nations Framework Convention on Climate Change (UNFCCC) on 2015 set targets for emissions reduction in order to ensure that the global average temperature is reduced to $1.5^{\circ} \mathrm{C}$. To achieve the goal specified in [4], purposeful movement towards «carbon neutrality» (net zero carbon footprint) is very important.

Analysis of recent research and publications. Various aspects of RES are studied in the works of M. Hubbert, N. Stern, M. Kaltschmitt, W. Streicher, H. Lund, B. Edwards, P. Stevens, A. Shydlovskyi, A. Prakhovnyk, S. Kudria, O. Solovei and O. Sytnyk. However, the issue of RES information and regulatory provision needs more detailed research.

Aim of the article. The aim of the article is to analyze of information and regulatory provision of the estimation of renewable energy sources towards justifying of theoretical and methodological bases for statistical estimation of renewables and developing scientific and practical recommendations for the implementation.

Research results. National and international normative and legal documents are the basis for methodological, regulatory and informational provision for statistical estimation of renewable energy sources is Ukraine [Ошибка! Источник ссылки не найден.]. The role of the state in RES development is important and decisive, it covers use and implementation of direct and indirect support, regulation and control tools. Fig. 1 represents the scheme of major documents that create legal basis for information provision for RES estimation.

Within previous 10 years a number of legal documents were adopted in Ukraine. This includes laws, resolutions of the Cabinet of Ministers, resolutions of the Ukrainian Parliament, regulations of the National Commission, which performs state regulation in the energy sector and utilities (NKREKP) and other normative and legal documents in the field of energy, particularly RES, on national, regional and local levels. Ukraine is a member of numerous international agreements that are in force in Ukraine in accordance with the rule of law. Such international regulatory documents have either direct effect or are implemented in Ukrainian legislation in the form of 
laws of Ukraine. Developers of the normative base at the oblast level also use the provisions of modern international conventions and protocols. Statistical methods used by the State Statistics Service of Ukraine and its subdivisions are being gradually harmonized according to the European norms and standards.

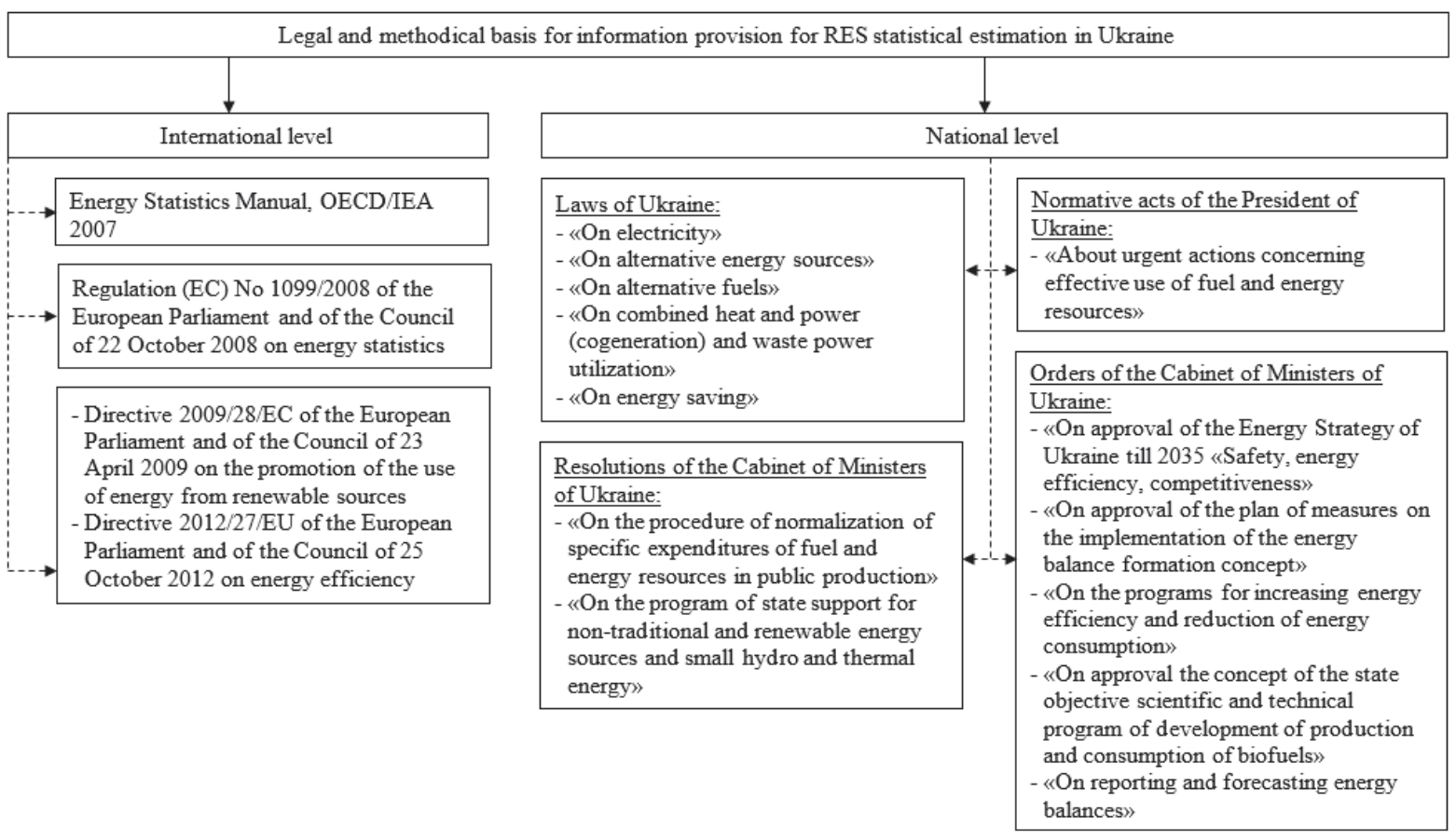

Fig.1. Legal and methodical basis for information provision for RES statistical estimation in Ukraine

Source: constituted by the author based on [6, 7, 8, 9, 10, 11, 12, 13, 14, 15]

The international legal framework is presented, first of all, by directives and agreements. Directive of the European Parliament and of the European Council 2009/28/EC of 23 April 2009 on the promotion of the use of energy from renewable sources and amending and subsequently repealing Directives 2001/77/EC and 2003/30/EC [6] declares the target to increase the share of RES energy consumption within total gross energy consumption in the European Union by $20 \%$ by 2020 and $27 \%$ by 2030, in line with. In addition, the amount of greenhouse gas emissions decreases by $20 \%$ compared to 1990 . Such policy should significantly reduce the negative impact of energy production on the environment and contribute to increasing energy security [16]. The Directive defines a common framework for the promotion of renewable energy. It states mandatory national targets for the share of RES energy in total final energy consumption, as well as the share of RES energy consumption in transport sector. The document introduces rules for statistical transfers between EU Member States, joint projects between the latter and with 
non-EU countries, guarantees of origin, administrative procedures, information, training and access to the grid for RES energy.

Directive 2012/27/EC of the European Parliament and of the Council of 25 October 2012 on energy efficiency, amending Directives 2009/125/EC and 2010/30/EC and repealing Directives 2004/8/EC and 2006/32/EC [7] sets the general framework for action to promote energy efficiency in the European Union (EU) in order to achieve the EU's pivotal goal of $20 \%$ energy efficiency by 2020 and pave the way for further energy efficiency in the coming years. The Directive sets rules that should remove barriers in the energy market and overcome inefficiencies of the market, which impede the supply and energy efficiency. In addition, it is foreseen to set national targets for energy efficiency by 2020 .

The Treaty establishing the Energy Community of 25.10.2005 (date of entry into force for Ukraine: 01.02.2011) [17] establishes cooperation among members of the Community aiming at launching an integrated natural gas and electricity market based on common interests and solidarity. The document provides for the creation of a stable regulatory and market structure that can attract investments in gas networks, in the network of production and transmission of electricity in such a way that all EU countries have access to sustainable and uninterrupted supply of gas and electricity, which is essential for economic development and social stability.

There are also three main technical documents that define requirements for the statistical system at the EU level. The first is the Regulation No. 1099/2008 of the European Parliament and of the Council of 22 October 2008 on energy statistics [14]. The document establishes a common framework for the production, transmission, evaluation and dissemination of comparative energy statistics in the Community. The Regulation applies to statistics relating to energy products and their aggregates in the Community. The second is the Energy Statistics Manual [8]. The document defines units and methodology in the field of energy statistics. The document is used by analysts of energy statistics of all countries. Third - Collection of statistical requirements (Statistical requirements compendium) [18]. It represents a tool for producers of official statistics, which summarizes the main reference information of European statistical products.

Gradual harmonization of Ukrainian legislation according to the European and international regulatory system is being performed with respect to the 
Ukrainian Constitution. Thus, one of the key documents, the Kyoto Protocol to the United Nations Framework Convention on Climate Change, was ratified by the Law of Ukraine No. 1430-IV of 04.02.2004 [19].

To increase the level of energy security, which includes stable supply and efficient use of energy, significant changes in the regulation are needed at national, regional and local levels. The Law of Ukraine «On electricity» [12] regulates relations in production, transmission, supply and use of energy, state supervision over the safe execution of works on the objects of electric power of all forms of ownership, safe operation of power equipment and state supervision over the modes of consumption of electric and thermal energy. Another document - the Law «On alternative energy sources» [9] defines the legal, economic, environmental and organizational principles for the use of renewable energy sources and facilitates expansion of their use in fuel and energy complex. The Law «On alternative fuels» [10] regulates production, extraction, and utilization of so called «alternative» fuels, including RES. In addition, the law provides incentives for increasing share of their consumption to up to $20 \%$ of the total fuel consumption in Ukraine by 2020 .

The Law of Ukraine «On combined heat and power (cogeneration) and waste power utilization» [11] defines and regulates energy saving of cogeneration units, as well as production, transmission and supply of electric and thermal energy from cogeneration units. This document creates the legal framework for increasing fuel efficiency in energy production or other technological processes, development and application electric and thermal energy combined production technologies, increase of energy supply reliability and security at the regional level, and attraction of investments for cogeneration units creation. Another important document is the Law of Ukraine «On energy saving» [13], which defines the legal, economic, social and environmental bases of energy saving for all enterprises, associations and organizations located on the territory of Ukraine, as well as for citizens.

Among the normative acts of the President of Ukraine, the key document is the Decree «About urgent actions concerning effective use of fuel and energy resources» (February 28, 2008, No. 174) [15].

It should be noted that in general RES and energy regulation on the regional and local levels does not always correspond to the current international and European requirements. However, the regional level has great opportunities to promote investment in the modern energy infrastructure for 
RES development. For example, the «Strategy for Energy Saving, Energy Efficiency and Development of Renewable Energy Sources in Dnipropetrovsk Region for 2018-2035» promotes sustainable consumption of energy and natural resources with wide introduction of RES utilization and its production localization. The document states complete abandonment of fossil fuels use in the form of a direct-effect provision with a gradual decrease of its share in energy production sector [20,21].

Conclusion. The RES normative legal framework in Ukraine is presented by extensive regulatory system. The Constitution of Ukraine is the basis and the first level of legal regulation. The second level is the norms of international law in the field of RES development. Following the Constitution, they define the strategic direction of the State concerning cooperation with international, European and foreign institutions and organizations. Such norms also require harmonization of Ukrainian legislation to current requirements of international law. Laws of Ukraine, resolutions of the Cabinet of Ministers of Ukraine and the Parliament, the documents of other governmental institutions at the national, regional and local levels constitute the third level of legal regulation in Ukraine. Further research on information and regulatory provision of RES will address the «green» tariffs and new forms of financial support for RES development.

\section{REFERENCES}

1. Ashden: Sustainable solutions. ashden.org. Retrieved from: http://www.ashden.org/ [in English].

2. Progress towards the Sustainable Development Goals (2017). Report of the SecretaryGeneral. United Nations. Economic and Social Council. un.org. Retrieved from: http://www.un.org/ga/search/view_doc.asp?symbol=E/2017/66\&Lang=E [in English].

3. United Nations Sustainable Development Goals. Energy. un.org. Retrieved from: http://www.un.org/sustainabledevelopment/energy/ [in English].

4. The Paris Agreement (2015). United Nations Framework Convention on Climate Change. unfecc.int.

Retrieved

from: https://unfccc.int/sites/default/files/english_paris_agreement.pdf [in English].

5. Sait Derzhavnoho ahentstva z enerhoefektyvnosti ta enerhozberezhennia Ukrainy [Website of the State Agency for Energy Efficiency and Energy Saving of Ukraine]. saae.gov.ua. Retrieved from: http://saee.gov.ua/ [in Ukrainian].

6. Directive 2009/28/EC of the European Parliament and of the Council of 23 April 2009 on the promotion of the use of energy from renewable sources and amending and subsequently 
repealing Directives 2001/77/EC and 2003/30/EC. eur-lex.europa.eu. Retrieved from: http://eur-lex.europa.eu/legal-content/EN/TXT/PDF/?uri=CELEX:32009L0028\&rid=1 [in English].

7. Directive 2012/27/EU of the European Parliament and of the Council of 25 October 2012 on energy efficiency, amending Directives 2009/125/EC and 2010/30/EU and repealing Directives 2004/8/EC and 2006/32/EC. eur-lex.europa.eu. Retrieved from: https://eurlex.europa.eu/LexUriServ/LexUriServ.do?uri=OJ:L:2012:315:0001:0056:en:PDF [in English].

8. Energy Statistics Manual (2004). iea.org. Retrieved from: https://www.iea.org/publications/freepublications/publication/statistics_manual.pdf [in English].

9. Zakon Ukrainy «Pro alternatyvni dzherela enerhii» vid 01.07.1994 r. № 555-VI [Law of Ukraine «On alternative energy sources» from 20.02.2003 № 555-VI]. zakon.rada.gov.ua. Retrieved from: http://zakon.rada.gov.ua/laws/show/555-15 [in Ukrainian].

10. Zakon Ukrainy «Pro alternatyvni vydy palyva» vid 14.01.2000 r. № 1391-XIV [Law of Ukraine «On alternative fuels» from 14.01.2000 № 1391-XIV]. zakon.rada.gov.ua. Retrieved from: http://zakon.rada.gov.ua/laws/show/1391-14 [in Ukrainian].

11. Zakon Ukrainy «Pro kombinovane vyrobnytstvo teplovoi ta elektrychnoi enerhii (koheneratsiiu) ta vykorystannia skydnoho enerhopotentsialu» vid 05.04.2005 r. № 2509IV [Law of Ukraine «On combined heat and power (cogeneration) and waste power utilization» from 05.04.2005 p. № 2509-IV]. zakon3.rada.gov.ua. Retrieved from: http://zakon3.rada.gov.ua/laws/show/2509-15 [in Ukrainian].

12. Zakon Ukrainy «Pro elektroenerhetyku» vid 16.10.1997 r. № 575/97-BP [Law of Ukraine «On electricity» from 16.10.1997 № 575/97-BP]. zakon.rada.gov.ua. Retrieved from: http://zakon.rada.gov.ua/laws/show/575/97-\%D0\%B2\%D1\%80 [in Ukrainian].

13. Zakon Ukrainy «Pro enerhozberezhennia» vid 01.07.1994 r. № 74/94-BP [Law of Ukraine «On energy saving» from 01.07.1994 p. № 74/94-BP]. zakon.rada.gov.ua. Retrieved from: http://zakon.rada.gov.ua/laws/show/74/94-\%D0\%B2\%D1\%80 [in Ukrainian].

14. Regulation (EC) No 1099/2008 of the European Parliament and of the Council of 22 October 2008 on energy statistics. eur-lex.europa.eu. Retrieved from: http://eurlex.europa.eu/legal-content/EN/ALL/?uri=CELEX\%3A32008R1099 [in English].

15. Ukaz Prezydenta Ukrainy «Pro nevidkladni zakhody shchodo zabezpechennia efektyvnoho vykorystannia palyvno-enerhetychnykh resursiv» vid 28.02.2008 r. № 174 [Decree of the President of Ukraine «About urgent actions concerning effective use of fuel and energy resources» from 28.02.2008 № 174]. zakon.rada.gov.ua. Retrieved from: http://zakon.rada.gov.ua/laws/show/174/2008 
16. Renewables 2016. Global Status Report (2016). ren21.net. Retrieved from: http://www.ren21.net/wp-content/uploads/2016/06/GSR_2016_Full_Report_REN21.pdf [in English].

17. The Energy Community Treaty. Council Decision 2006/500/EC of 29 May 2006 on the conclusion by the European Community of the Energy Community Treaty. eurlex.europa.eu. $\quad$ Retrieved from: https://eur-lex.europa.eu/legalcontent/EN/TXT/?uri=celex:32006D0500 [in English].

18. Statistical requirements compendium. 2010 edition (2010). Eurostat Methodologies and Working papers. ec.europa.eu. Retrieved from: http://ec.europa.eu/eurostat/documents/3859598/5915733/KS-RA-10-007-ENEN.PDF/ccead43d-57f3-4dce-aa7d-34e51caadd7d?version=1.0 [in English].

19. Kyoto Protocol to the United Nations Framework Convention on Climate Change (1998). United Nations Framework Convention on Climate Change. unfccc.int. Retrieved from: https://unfccc.int/sites/default/files/kpeng.pdf [in English].

20. Khazan P.V. (2018). Vprovadzhennia normatyvno-pravovoi bazy dlia rozvytku vidnovliuvanykh dzherel enerhii na prykladi Dnipropetrovskoi oblasti [Implementation of the regulatory framework for renewable energy sources development in Dnipropetrovsk region]. Materialy mizhnarodnoi naukovo-praktychnoi konferentsii «Aktualni problemy modeliuvannia ta upravlinnia sotsialno-ekonomichnymy systemamy $\mathrm{v}$ umovakh hlobalizatsii», Kyshakevych B.Yu. (Ed.). Drohobych: Redaktsiino-vydavnychyi viddil Drohobytskoho derzhavnoho pedahohichnoho universytetu imeni Ivana Franka [in Ukrainian].

21. Rishennia Dnipropetrovskoi oblasnoi rady «Pro stratehiiu enerhozberezhennia, enerhoefektyvnosti ta rozvytku vidnovliuvanykh dzherel enerhii Dnipropetrovskoi oblasti na 2018 - 2035 roky» vid 01.12.2017 r. № 275-11/VII [Order of Dnipropetrovsk regional council «On Strategy for Energy Saving, Energy Efficiency and Development of Renewable Energy Sources in Dnipropetrovsk Region for 2018-2035» from 01.12.2017 № 275-11/VII]. oblrada.dp.gov.ua. Retrieved from: http://oblrada.dp.gov.ua/rishennia/sklikannia-7/xi-sesiya/\%E2\%84\%96-27511vi\%D1\%96-01-12-2017/ [in Ukrainian]. 